\title{
HVEM ER ABRAHAMS BARN?
}

Tekstlige refleksjoner om identitet og hybridisering i hellenistisk jødedom ${ }^{1}$

\author{
Turid Karlsen Seim
}

\section{Jødisk og kristen identitet}

I begynnelsen var det verken lett eller selvsagt å se forskjell på kristne og jøder. De kristne var å oppfatte som enda en jødisk variasjon, og når de etter hvert etablerte en egen og separat identitet var dette i mange henseende en reforhandlet jødisk identitet, der de påberopte sin rett til noen jødiske identitetmarkører og forkastet andre. Likhet var i dette like viktig som forskjellighet. Men den likheten en insisterte på, ble likevel gjennom den like tydelige forskjellighet nettopp en del av forskjelligheten. Forhandlingene fant sted innenfor en større diskurs i samtiden der identitet ble redefinert og grenser trukket på ny, ikke minst innenfor hellenistisk jødedom. Der hadde en, mange steder gjennom generasjoner, definert seg i avstand fra goyim (de andre folkeslag), samtidig som en inngikk i hybridiserende prosesser. Ulike grupper kunne trekke grensene forskjellig, og i en viss forstand var kristendommen resultat nettopp av en slik hybridiseringsprosess.

I motsetning til den inkluderende gresk-romerske kultur og religion som lett kunne finne plass til ytterligere en kult bare den ikke utelukket alle andre og særlig ikke de statsbærende kultiske uttrykk, var jødedom og kristendom eksklusive i sin selvforståelse. De lot seg ikke uten videre inkludere i en religiøs pluralisme som fungerte i henhold til en kompilasjons- eller addisjonsmodell. Derfor måtte de søke andre overlevelses- og tilpasningsstrategier der avgrensning og grensesettende markører inngikk.

\section{Abraham som seleksjonsmarkør}

En viktig seleksjonsmarkør var Abraham og tradisjonene om ham. Abraham var den jødiske stamfar par excellence, og det å være jøde var å tilhøre hans ætt, være hans avkom. Samtidig var Abraham i jødisk tradisjon også den første proselytt, den som Gud hadde kalt fra et annet sted og et annet folk til å bli denne stamfar. Abrahams oppbrudd fra Ur i Kaldea til det land som ble ham lovet, var dessuten forbundet med et løfte om universell velsignelse: i ham "skulle alle jordens slekter velsignes". Abrahamstradisjonen rommet derfor både en understrekning av det partikulært eksklusive og en åpning mot det universelt gyldige.

\footnotetext{
${ }^{1}$ Dette er en forkortet og sterkt bearbeidet versjon av en lengre artikkel tidligere publisert på engelsk (Seim 2001). Den engelske artikkelen er mer innrettet mot utforskningen av det som kalles “Abraham-language” og utreder de terminologiske spørsmålene i tillegg til i detalj å analysere tekstavsnitt. Denne versjonen på norsk er dreidd mot å belyse spørsmålet om identitet og mulighetene for det som er blitt kalt "en tredje identitet”.
} 
Fra det første århundre etter kristen tidsregning finnes flere tekster som tematiserer spørsmålet om tilhørighet til Abrahams ætt. Hvem er Abrahams barn? Selve det faktum at spørsmålet stilles og stadig drøftes i tekster fra denne tiden, er et tegn på at svaret ikke lenger var selvsagt. Etablerte identitetsmarkører ble identifisert på nytt og grenseforhandlinger pågikk stadig, både på det jødiske kjerneområde i Palestina og i diasporaen der et betydelig flertall av jødene levde i prinsippet som "i fremmed land”.

I sitt brev til menighetene i Galatia bruker Paulus Abrahamstradisjonen aktivt til å redefinere hvem som er å regne for Abrahams barn. Han er opptatt av det universelt rettede løfte om velsignelse som langt tilbake var gitt til Abraham og hans ætt. På skriftlærd vis leser han - i dette tilfelle den greske teksten til Genesis (1 Mosebok) meget nøye og poengterer den merkverdighet at Abrahams ætt, sperma, er et entallsord. Siden ingen detalj er likegyldig, må dette ha sin spesielle forklaring. Denne ene sperm, hevder han, må derfor være Kristus. Dette åpner for den tanke at alle de som er døpt og i dåpen har "ikledd seg Kristus", blir Guds sønner slik Kristus er Guds sønn, men også Abrahams sperma slik Kristus er det. Dermed er de Abrahams ætt og arvinger til det løftet som Abraham mottok i tro.

I dette resonnementet, som Paulus riktignok aldri gjentar, blir den partikulære singularitet (Abrahams ene sperma) rituelt applisert og mangfoldiggjort. Det innebærer at etablerte kategorier for inndeling og identifisering som det å være jøde til forskjell fra ikke-jøde, det å være slave til forskjell fra fri, og kjønnsdikotomien mellom mannlig og kvinnelig oppheves i den enhet (ikke likhet!) som den felles og rituelt etablert identifikasjon med Kristus skaper.

Kristus, Guds sønn og Abrahams ene sperma, blir de kristnes rituelt etablerte 'tredje identifikasjon'.

\section{Fjerde Makkabeerbok: Stoisk jødedom}

I det følgende skal jeg imidlertid særlig konsentrere meg om et skrift som i utgangspunktet ikke er kristent, selv om det i likhet med andre greskspråklige jødiske apokryfe og pseudepigrafiske tekster etter hvert ble lest og brukt og også bevart av kristne, som skattet det høyt som en martyrfortelling. Men 4 Makkabeerbok, som skriftet kalles, har sin opprinnelse innenfor hellenistisk jødedom, og det gjenforteller beretningen om de martyrer, som under den makkabeiske oppstand mot fremmedveldet, døde på heroisk vis. En tidligere versjon foreligger i 2 Makkabeerbok, men der er fortellingen om de makkabeiske martyrer bare et innslag i en mer omfattende fremstilling av oppstanden. 4 Makkabeerbok utvider og utvikler det patetiske potensialet i den tidligere versjonen, og den konverteres til et filosofisk skrift om hvordan selv de sterkeste lidenskaper kan mestres. Skriftet presenterer seg som en fremstilling av "hvorvidt den fromme fornuft kan beherske lidenskapene” (4 Makk 1.1). Den dyd som skal etterstrebes er andreia, det vil si det mandige mot (Moore and Anderson 1998). I tråd med dette er 4 Makkabeerbok gjennomsyret av stoiske idealer, selv om forsøkene på å henholde den filosofiske terminologien mer presist til bestemte skoleretninger ikke har lyktes. Antagelig representerer den en eklektisk blanding av 
termer fra forskjellige perioder og skoler (deSilva 1998, 13). Poenget er bredt å forholde seg til tidens filosofiske allmenngods og smelte det sammen med martyrfortellingen til et kompromissløst forsvar for jødisk fromhet og lovtroskap: Lydighet mot den jødiske lov er den fullkomne oppfyllelse av de allment aksepterte filosofiske idealer og vice versa.

Dateringen av skriftet er usikker, men det er ikke usannsynlig at det stammer fra en gang i det første århundre. Heller ikke opprinnelsessted lar seg sikkert fastslå, men det er blitt til i den jødiske diaspora med gresk som førstespråk. Mange har foreslått Antiokia i Syria, hvor det på denne tid var en stor jødisk befolkningsgruppe, men det samme gjelder for deler av Lille-Asia. Skriftets selvpresentasjon som er sitert ovenfor, kan leses som et åpent forsvar for en allment rettet filosofisk proposisjon eller tese, eller kan endog tilsi at det skulle dreie seg om et forsvar av jødedommen overfor et ikkejødisk publikum. Imidlertid gjør konklusjonen det utvilsomt klart at skriftet retter seg til jøder: 4 Makkabeerbok er skrevet av jøde(r) for jøder. Men det må være jøder som var tilstrekkelig helleniserte til å trenge, eller i hvert fall finne nyttig eller kunne glede seg over en slik påvisning av at dere jødiske livsstil var forenlig med de greske filosofiske idealer.

Skriftets form og stil styrker dette inntrykket. Språket som er gresk, beherskes flytende, retoriske forventninger imøtekommes, og forfatteren er bredt fortrolig med den filosofiske og etiske diskurs i samtiden. Det hele vitner om en forfatter som kjenner seg hjemme i sin tids generelle kulturelle dannelse, og dermed om muligheten for at jøder kunne forbli hengivne i forhold til sin nedarvede religion uten å ghettoiseres. Den allmenne filosofiske og etiske diskurs blir den bro, som gjør dette mulig og endog prisverdig.

En heroisk martyrfortelling fra en tid med konfrontasjon og krise og en traumatisk erfaring om at døden er å foretrekke fremfor å forråde sin jødiske tilhørighet og identitet gjennom å gi etter for den fremmede herskers krav om å spise svinekjøtt, blir ikke fortalt for å fremme motstandsvilje og standhaftighet i en lignende konfliktsituasjon. Tvert i mot blir den gjengitt for å forsvare en jødedom som definerer seg i et korresponderende forhold til sine gresk-romerske (hellenistiske) omgivelser. Den potensielle konflikt undermineres gjennom markering av likhet. Skriftet hevder at jødisk lovobservans er det samme å la seg styre av den fromme fornuft og derfor uttrykk for den ypperste dyd, som de makkabeiske martyrer er de beste og edleste vitner om. Det ekstreme tilfelle brukes til å fremme det moderate. ${ }^{2}$

I dette perspektiv er det interessant å se hvordan det spredt i 4 Makkabeerbok finnes et sjeldent utvalg av referanser til Abrahamstradisjonene. Det er typisk at de opptrer som hentydninger eller henvisninger som verken blir forklart eller utarbeidet. Det samme kan iakttas i mange andre jødiske tekster, - hentydninger er åpenbart tilstrekkelige for lesere som selv er fortrolige med tradisjonene (Sandmel 1971, 37f). De

2 Både Klauck (1989, 663ff) og deSilva (1998, 11 og 45) argumenterer overbevisende for at 4 Makkabeerbok ikke er skrevet i en krisetid for å fremme martyriet som eksemplarisk. Det dreier seg heller om å la det ekstreme tilfelle si noe om hvordan mer dagligdagse tilpasningsproblemer kan løses. 
er signaler som fungerer bekreftende i forhold til en etablert identitet samtidig som det gir fleksible muligheter for å markere noen tradisjonstrekk og ignorere andre.

\section{Heroisk identifikasjon: Abraham som moralsk typos}

Henvisningene til Abraham forekommer først og fremst når de makkabeiske helter karakteriseres. I sin siste tale før flammene fortærer ham, bruker den gamle Eleazar betegnelsen Abrahams sønner (paides) som en jødisk ærestittel. Den innebærer at de som skal se ham dø og vet hva som venter dem selv, ikke må vise seg feige $(6.17,22)$. Betegnelsen er altså et argument mot feighet og mangel på selvbeherskelse. Den har en formanende eller didaktisk funksjon som både forutsetter en etablert etnisk og religiøs identitet og samtidig utvikler den gjennom å foreskrive hva den i gitte situasjoner skal innebære.

Etter Eleazar blir syv brødre torturert og drept, en etter en, den eldste først. De imøtekommer alle kravet om hva det innebærer å være Abrahams sønner, i det de dør modig og urokkelig. I 9.21 blir den eldste karakterisert som en storsinnet og 'abrahamittisk' ung mann. Dette er en særegen språklig konstruksjon, som adjektiviserer navnet Abraham i stedet for å benytte etablert slektsskapsterminologi. Det signaliserer en overgang fra termer som spiller på nedstamming fra Abraham og dermed folketilhørighet til en mer karakteriserende eller moralsk kvalifiserende terminologi, som handler om at visse egenskaper er abrahamittiske.

Det er misvisende - om enn interessant - at oversettelser av 4 Makkabeerbok har en tendens til å gjeninnføre slektsskapsterminologi slik at "en abrahamittisk ung mann” blir til "en sann sønn av Abraham". Det samme skjer med en tilsvarende konstruksjon i 18.20 som gjelder moren til de syv brødrene. I den greske teksten kalles hun “abrahamittinne”, fordi hun utviser abrahamittiske kvaliteter. Men vanligvis oversettes dette som om det primært gjaldt nedstamming og slektskap, og hun blir en Abrahams datter - noen ganger riktignok en "sann" sådan. ${ }^{3}$ Tilføyelsen "sann” i noen oversettelser impliserer at det finnes sønner og døtre som ikke er sanne, og introduserer dermed et typologisk element slik at den genetiske koden ikke blir automatisk, men krever ytterligere kvalifikasjon. Dermed bekreftes, gjennom denne indirekte mulighet for benektelse, den forflytning av fokus som den greske teksten faktisk foretar fra etniske/genetiske markører til moralske.

De øvrige referansene til Abraham i 4 Makkabeerbok er en fluktuerende blanding av disse to typene av termer/markører. Nedstamming fra Abraham har betydning i den grad etterkommerne viser seg å være 'abrahamske', det vil si lever opp til de idealer og dyder som Abraham representerer. Det skapes rett og slett helt nye ord basert på navnet Abraham, der hans betydning som moralsk eksempel, typos, blir språklig styrende.

Den del av Abrahamstradisjonen som i hovedsak definerer Abraham som moralsk typos, er fortellingen i 1 Mos 22 om hvordan Abraham (nesten) ofret sin eneste sønn

\footnotetext{
${ }^{3}$ Et hederlig unntak er Deissmanns oversettelse. For en mer utførlig oversikt over ulike oversettelser, se Seim 1994, 46.
} 
Isak. Selv om han til slutt slapp å gjennomføre offeret, var han villig til det. Dette var den episode som i bredt i jødisk tradisjon mer enn noe ble lest som bevis på Abrahams lydige og urokkelige tro og tillit til Gud (Baird 1988, 368; Siker 1991, 23). Noen ganger ble den også brukt som belegg for Isaks villighet til å blir ofret (Anderson 1998, 558). I 4 Makkabeerbok spilles det eksplisitt på denne fortellingen og de syv brødrene identifiseres både med Abraham og med Isak. Men det er betegnende at, når 4 Makkabeerbok refererer til fortellingen om Abrahams villighet til å ofre Isak, finnes ingen henvisning til hans tro og/eller lydighet. Den er nok forutsatt, men det som interesserer, er Abrahams standhaftige mot i en situasjon der det kunne være lett å gi etter for de følelser han måtte ha for sin sønn.

\section{Abraham og martyrmoren som eksempel på mannsmot}

Parallellen mellom fortellingen om Abrahams ofring av Isak og martyrmorens rolle i 4 Makkabeerbok er åpenbar. Hun må være vitne til at alle sønnene hennes tortureres og drepes. Hennes kvaler og lidelse er ikke så mye hennes egen martyrdød, men det morsmartyrium det er å se syv sønner dø en grusom død for øynene på seg. Hennes identitet i fortellingen er primært definert av moderskapet, og hun kalles også bare for "Moren" - til tross for senere tradisjons mange navneforslag. ${ }^{4}$

Mødre var i sterkere grad enn fedre antatt å ha en dypere sympati, medlevelse, med barna sine. Dessuten var den kvinnelige forstand (nous) regnet som svakere og mer vankelmodig enn menns, slik at de lettere ga etter for sin sympati og følelsesmessige inklinasjon (Moore and Anderson 1998, 266; Young 1991, 75f). Morens relasjon til sønnene og hennes varme følelser for dem blir da også utførlig beskrevet. Men hun lar den fromme fornuft seire over sine naturlige tilbøyeligheter og moderlige følelser og står kampen ut. Hennes selvbeherskelse og mannsmot viser seg mer tydelig i hennes evne til å beherske sin moderlige medfølelse med sønnene enn i den uforferdethet hun viser ved til slutt å kaste seg i ilden. ${ }^{5}$ Hun endog oppmuntrer og overtaler sønnene til frimodig å dø, og hun sørger ikke over dem. Dette beskrives som at hun føder dem på ny, denne gang til udødelighet. Det er også en barnefødsel “der Abraham er far” og mot slutten av skriftet kalles brødrene “abrahamitinnens syv sønner”. Dermed er også moren Abrahams-lik samtidig som hennes moderskap har sin korrespondanse i Abrahams farskap. Det vil si at hun settes på linje med Abraham, og hun er - ikke Abrahams datter - men, som den greske tekst sier, datter av det mannsmot han viste. Hun blir det ideelle eksempel på andreia, mannsmot, og kan også kalles “nasjonens mor”. Slik blir hennes kvinnelighet understreket, samtidig som hun gjennom sitt standhaftige mot oppnår den maskuline status som dette gir. Hun blir derfor i mer enn ett henseende et eksempel på en 'tredje identitet'.

\footnotetext{
${ }^{4}$ Det finnes mange navneforslag i senere både jødisk og kristen tradisjon: Hannah, Miriam bat Tanhum, Solomone eller Mart Simouni (Young 1991, 67).

${ }^{5}$ Det vil her føre for langt å gå inn på spørsmålet om hun begår selvmord, og også de renhetsforestillinger som måtte begrunne at hun for enhver pris unngår at hennes kropp blir berørt.
} 
På mange måter overgår fortellingen i 4 Makkabeerbok den prototypiske fortellingen om Abrahams ofring av Isak. I senere jødisk tradisjon (Lamentationes Rabbah 1.50 fra 5/6 århundre e.v.t.) finnes en versjon som understreker dette. Der sier moren til den yngste og siste sønnen i det han skal drepes:

Min sønn, gå til patriarken Abraham og si til ham: Min mor sa dette: Smykk deg ikke med din rettferdighet fordi du bygde et alter og ofret din sønn Isak. Sannelig, vår mor bygde syv altre og ofret på en dag syv sønner. Ditt var bare en prøve, men mine var på alvor (Midrash Rabba 1.50).

Her er moren ikke bare jevnbyrdig med Abraham, hun er ham overlegen.

\section{Abrahamstilhørighet: partikulær eksklusivitet og tredje identifikasjon}

Abrahamsreferansene i 4 Makkabeerbok er tilsynelatende en spredt blanding, men nærmere analyse viser at de like fullt danner et sammenhengende og konsistent mønster. ${ }^{6}$ Det spiller på et veletablert og vanlig tradisjonskompleks og ordfelt der det jødiske folk forsto seg som Abrahams ætt og dermed som Abrahamspaktens og løftets folk. Dette var deres eksklusive identitetsmarkører, det som gjorde dem spesielle og utvalgte, det som for enhver pris skulle forsvares. Kombinert med Sinaipaktens tilkjennegivelse av Guds vilje i Loven, var denne identitet allerede definert gjennom en kultisk praksis i Jerusalem og gjennom et gjennomregulert levesett. Forræderiets uttrykk var å spise svinekjøtt. Da ble grenser overskredet på utillatelig vis. Slik sett var Abrahamsslektskap allerede kvalifisert som lydighet mot loven og dermed knyttet til forventede idealer eller regler for livsførsel. Det som særpreger 4 Makkabeerbok er forsøket på å bringe dette i uløselig samklang med samtidens generelle etiske idealer. Lovoppfyllelsen i sin mest ekstremt separatistiske form, i sin insistering til døden på at en ikke kan gjøre som "de andre” eller hva den fremmede overmakt forlanger, er samtidig en ubestridelig demonstrasjon av disse andres ypperste dyd. Her gjøres de på egne premisser til skamme når den fromme fornuft seirer over selv de sterkeste lidenskaper i en situasjon der livet står på spill.

I 4 Makkabeerbok innebærer dette at tilskrivelsen av Abrahamstilhørighet som genetisk, etnisk markør der forestillinger om nedstamming og blodsbånd var språklig dominerende, konverteres til æresbetegnelser, der det avgjørende er om de viser abrahamittiske kvaliteter. Dette kan språklig spores i en sofistikert veksling mellom etablert genetisk terminologi og et sett med nyskapte Abrahamsbaserte ord, som vektlegger abrahamslikhet. ${ }^{7}$ Det gjelder å vise mannsmot slik den stoiske helt Abraham gjorde. Jødisk ethos presenteres som meningsfull og holdbar i et hellenistisk perspektiv. Ja, den er ikke bare kompatibel med gjengs god moral, den er det meste annet overlegent i sin praksis av de stoiske dyder.

\footnotetext{
${ }^{6}$ Når Sandmel hevder at henvisningene til Abraham i 4 Makkabeerbok er “quite incidental”, tar han feil.

${ }^{7}$ Mer generelt hevder deSilva at evnen til skape sammensatte ord og nye former av et allerede eksisterende vokabular, inngår i forfatterens suverene mestring av det greske språk (1998, 12f).
} 
I skriftets avsluttende del appelleres det ikke bare til jøder, perspektivet blir universelt: de makkabeiske martyrer beundres av hele menneskeheten. Et skrift som handler om hvordan jøder motsetter seg integrasjon eller assimilering, bevitner samtidig nettopp det. Jødisk partikularisme smelter sammen med universalisme, og stamfaren Abraham smeltes om til å bli en moralsk typos. Den fortelling som markerer hvilken grense som ikke kan overskrides uten at den tradisjonelt etablerte identitet må oppgis, finner andre veier til overskridelse av den samme grense.

4 Makkabeerbok er ikke som 2 Makkabeerbok et historieverk. Det er en filosofisk fremstilling, som forsvarer en første identitet gjennom å skape en tredje. Det skjer gjennom skifte fra en historisk-genetisk diskurs ("husk hvor/hvem dere kommer fra"), til en etisk-filosofisk typologi. Abrahams-stemplet består, men hva det innebærer er reforhandlet. En tredje identitet skapes gjennom overgripende moralske kategorier.

\section{Fader Abraham i Lukas-Acta}

Det nytestamentlige forfatterskapet som tillegges Lukas, dvs. evangeliet etter Lukas og Apostlenes gjerninger (Lukas-Acta), har noen helt spesielle språklige særegenheter felles med 4 Makkabeerbok. Det er derfor mulig at de har hatt en eller annen form for felles bakgrunn innenfor hellenistisk jødedom, deriblant en opptatthet av visse Abrahamstradisjoner. ${ }^{8}$ Det kan derfor være grunn til ganske kort å se om vi i LukasActa kan spore lignende trekk som de vi har sett i 4 Makkabeerbok.

Referanser til Abraham spiller en betydningsfull rolle i Lukas-Acta. Mesteparten er også i dette tilfelle korte henspillinger, men det finnes også mer utførlige henvisninger til narrative sekvenser. Imidlertid er det påfallende at fortellingen om Abrahams ofring av Isak er like fraværende i Lukas-Acta, som motivet om Abrahams tro er det i 4 Makkabeerbok. For Lukas var Abraham først og fremst den utvalgte mottaker av det Guds løfte som fremdeles gjelder for hans etterkommere og arvtakere. Abrahamsrelatert språk forekommer derfor primært i sammenhenger som trekker opp frelseshistoriske perspektiver. Lukas gjør her bruk av jødisk materiale uten vesentlige forandringer eller kristen omfortolkning (Baird 1988, $368 \mathrm{f}$ og Moxnes 1980, 171 og 176). Interessen for Abraham som typos er marginal og fullstendig underordnet et perspektiv der historien drives frem gjennom guddommelige løfter som så oppfylles. Abrahams aktuelle relevans er de som i Lukas’ samtid er å regne som hans etterkommere og dermed som arvinger til det løfte stamfaren en gang fikk av Gud.

Samtidig er "Abrahams barn" heller ikke i Lukas-Acta, en automatisk etnisk betegnelse, en ren omskrivning for det å være jøde. Lukas knytter her an til jødiske tradisjoner, som understreker at den jødiske historie inneholder rikelig med eksempler på at det i folket selv alltid har vært motstand mot Gud. Oppfyllelsen av løftene har alltid vært kontroversiell og har måttet kjempes igjennom. Slik bebudes det allerede i Marias lovsang (Luk 1.46-55) at når Gud innfrir løftet til Abraham, innebærer det drastiske forandringer i normalt etablerte maktstrukturer. Siden finnes henvisningene til

\footnotetext{
${ }^{8}$ Denne observasjonen skylder jeg Dahl (1976, 69f).
} 
Abraham nettopp i sammenhenger der uventede og frigjørende handlinger skjer. Enkelttilfeller eksemplifiserer det allmenne.

De tre tilfellene i evangeliet der bestemte personer anerkjennes som Abrahams barn, kjennetegnes av sosial stigmatisering og omgis av kontrovers: En krumbøyd kvinne, som har vært bundet av Satan i atten år, karakteriseres som Abrahams datter; den uglesette tolleren Sakkeus kalles en Abrahams sønn; tiggeren Lasarus bæres av engler til Abrahams fang. Abrahamstilknytningen tjener som begrunnelse for hendelsen (slik som helbredelsen av den krumbøyde kvinnen), den er ikke resultatet av den. Den status de allerede har som Abrahams sønner og døtre, erkjennes og gis konsekvenser.

Det de tre har felles, er sosial sårbarhet og marginalisering - ulike former for nød. Her påberopes ingen egenskaper eller dyder som skulle kunne kvalifisere dem spesielt som Abrahams barn. Til tross for hva enkelte fortolkere har villet mene, er den krumbøyde kvinnen ikke spesielt beskrevet som fattigfrom. Sakkeus er ikke en Abrahams sønn fordi han angrer og gjør bot. ${ }^{9}$ De er i forhold til heltemartyrene i 4 Makkabeerbok, uberettigede Abrahamsbarn - de utviser ingen spesielt abrahamittiske egenskaper. I forhold til 4 Makkabeerbok er dette desto mer påfallende som også Lukas helt klart er påvirket av og implisitt gjør bruk av stoiske idealer i sin fremstilling. Martyrhelter som Jesus og Stefanus demonstrerer stoisk ro og emosjonell kontroll. Men Lukas gjør ikke bruk av spesifik stoisk terminologi, og det stoiske paradigme forbindes aldri med Abraham. Han er ikke den heroiske typos, det eksempel som ethvert sant Abrahams barn må leve opp til.

Den selektive bruk av Abrahamsterminologien skjer på et helt annet grunnlag og miskjente barn av Abraham synliggjøres. Den sosiale ekspansjon skjer ikke fordi Lukas spiritualiserer eller åpner opp for en universalisert mulighet for Abrahamstilhørighet. Tvert i mot fastholdes Abraham i den historiske, fortidige rolle som den stamfar, som opprinnelig fikk løftet om velsignelsen: Lukas' “interest in Abraham and his archaizing tendency in general bear the stamp of an age that looked back at classical times and considered antiquity an indication of value” (Dahl 1976, 84).

Lukas skaper heller ingen nye Abrahams barn. Han gjør ikke som Paulus og argumenterer for at det er de kristne, som er Abrahams sanne barn - enten i kraft av dåpen (Gal 3) eller i kraft av troen (Rom 4). Tvert i mot er og forblir det å være Abrahams barn i Lukas-Acta et jødisk privilegium. ${ }^{10}$ Det betyr ikke, at frelsen

\footnotetext{
${ }^{9}$ Siker hevder at Lukas diskvalifiserer nedstamming og bruker Abraham til å fremme to forskjellige former for frelse: en som er barmhjertighet mot de fattigfromme (anawim) og en gjennom syndernes anger og bot. Magnificat som reflekterer Anawim-tradisjonen, er uttrykk for den første som så konkretiseres gjennom helbredelsen av den krumbøyde kvinnen. Døperen Johannes botsforkynnelse og ord om at Gud kan oppreise Abraham barn av steiner, er uttrykk for den andre som blir konkretisert gjennom tolleren Sakkeus. I fortellingen om den rike mann og Lasarus løper de to formene sammen. Dette innebærer at Siker må hevde både at den krumbøyde kvinnen er fattigfrom og at Sakkeus angrer og gjør bot (Siker 1991, 111ff). Det resulterer også i at hans overgripende tese er at ikke-jøder (Gentiles) ønskes velkommen som Abrahams barn, mens jødene gjøres arveløse.

${ }^{10}$ Dahl 1976, 77f, 82; senere fulgt opp i Jervells mange arbeider om Lukas-Acta, senest Actakommentaren i 1998.
} 
reserveres for dem - også ikke-jøder (goyim, dvs. 'folkeslagene') blir frelst, og på Lukas' tid har ikke-jøder høyst sannsynlig dominert de fleste kristne menigheter. Men de kan ikke på samme måte påberope seg Abraham. I forhold til Paulus kristianiserer ikke Lukas Abraham, og i forhold til det jødiske 4 Makkabeerbok universaliserer han ham heller ikke gjennom grenseoverskridende filosofisk-etiske idealer.

Den kristne identitet må forholde seg til den jødiske, men den verken erstatter den eller erobrer den. Lukas’ verk begynner i Jerusalem, men det slutter i Roma.

\section{Litteratur}

BAIRD, W.

1988 “Abraham in the New Testament: Tradition and Identity”, Interpretation 42, 367-79.

DAHL, N.A.

1976 "The Story of Abraham in Luke-Acts", Jesus in the Memory of the Early Church, Minneapolis, 66-86.

DeSilva, D.A.

19984 Maccabees, Sheffield.

JERVELL, J.

1998 Die Apostelgeschichte, Meyers kritisch-exegetischer Kommentar über das Neue Testament, Göttingen.

KLAUCK, H.-J.

1989 4. Makkabäerbuch, Jüdische Schriften aus hellenistisch-römischer Zeit, 3 vol., Gütersloh.

MOORE, S.D AND J.C. ANDERSON

1998 “Taking It like a Man: Masculinity in 4 Maccabees”, Journal of Biblical Literature 117, 249-75.

MOXNES, $\mathrm{H}$.

1980 Theology in Conflict. Studies to Paul's Understanding of God in Romans, Leiden.

SANDMEL, S.

1971 Philo's Place in Judaism: A Study of Conceptions of Abraham in Jewish Literature, New York.

SEIM, T.K.

1994 The Double Message. Patterns of Gender in Luke-Acts, Edinburgh.

1999 "Children of the Resurrection. Perspectives on Angelic Asceticism in Luke-Acts", L.E.Vaage \& V.L. Wimbush, eds., Asceticism and the New Testament, London, 115-25.

2001 "Abraham, Ancestor or Archetype? A Comparison of Abraham-Language in 4 Maccabees and Luke-Acts”, A.Y. Collins \& M.M. Mitchell, eds., Antiquity and Humanity. Essays on Ancient Religion and Philosophy. Presented to Hans Dieter Betz on His $70^{\text {th }}$ SIKER, J.S. Birthday, Tübingen, 27-42.

1991 Disinheriting the Jews. Abraham in Early Christian Controversy, Louisville.

SMith, A.

1999 “'Full of Spirit and Wisdom’: Luke’s Portrait of Stephen (Acts 6:1-8:1) as a man of SelfMastery”, L.E. Vaage and V.L.Wimbush, eds., Asceticism and the New Testament, New York, 97-114. 
YounG, R.D.

1991 "The 'Woman with the Soul of Abraham': Traditions about the Mother of the Maccabean Martyrs”, A.-J.Levine, ed., "Women Like This”: Perspectives on Jewish Women in the Greco-Roman World, Atlanta, 67-81.

\section{Summary}

The article, "Who are the Children of Abraham? Reflections on Identity and Hybridisation in Hellenistic Judaism", explores how a core set of terms in the discourse about Jewishness in Antiquity is being renegotiated in various ways by Jews as well as Christians. This happens in a Diaspora context where the redefining of boundaries and identity markers was especially urgent not only in situations of conflict but also in everyday life. Special attention is given to 4 Maccabees, a 1 century CE Jewish martyrology.

Turid Karlsen Seim

Professor

Universitetet i Oslo 